\title{
Parathyroid Gland Chief Cell
}

National Cancer Institute

\section{Source}

National Cancer Institute. Parathyroid Gland Chief Cell. NCI Thesaurus. Code C33266.

The primary cell of the parathyroid gland. Its contains secretory granules, large Golgi complexes, and moderate numbers of mitochondria. It produces parathyroid hormone. The cells occur in sheets interspersed with areas of fatty tissue. Occasionally the cells are arranged in follicles. 